\title{
RAW COW MILK THERMOSTABILITY AND ITS RELATIONS TO OTHER INDICATORS
}

\author{
Oto Hanuš ${ }^{1}$ Eva Samková², Gustav Chládek³, Marcela Klimešová ${ }^{1}$, \\ Petr Roubal ${ }^{1}$, Irena Němečkovál, Radoslava Jedelskál, Jaroslav Kopeckýl \\ ${ }^{1}$ Dairy Research Institute Ltd., Ke Dvoru 12a, 16000 Prague 6, Czech Republic \\ ${ }^{2}$ South Bohemia University in České Budějovice, Faculty of Agriculture, Branišovská 1160/31, 37005 České \\ Budějovice 2, Czech Republic \\ ${ }^{3}$ Mendel University in Brno, Faculty of Agronomy, Zemědělská 1665/1, 61300 Brno-Černá Pole, Czech Republic
}

To cite this article: HANUŠ OTO, SAMKOVÁ EVA, CHLÁDEK GUSTAV, KLIMEŠOVÁ MARCELA, ROUBAL PETR, NĚMEČKOVÁ IRENA, JEDELSKÁ RADOSLAVA, KOPECKÝ JAROSLAV. 2018. Raw Cow Milk Thermostability and its Relations to Other Indicators. Acta Universitatis Agriculturae et Silviculturae Mendelianae Brunensis, 66(5): 1127-1134.

To link to this article: https://doi.org/10.11118/actaun201866051127

\begin{abstract}
The aim was to evaluate the chosen relationships among milk composition, factors of primary milk production and milk thermostability (TES) on large data file during whole season (n 2,829). The results showed the TES mean $20.71 \pm 8.19$ minutes (geometric mean 19, median 20 minutes), from 3 to 57 minutes. Variation coefficient was 39.6\%. The highest monthly mean was in September (23.98 \pm 7.97 , vx 33.3\% and xg 22.4 min.) and the lowest in January (16.5 \pm 7.17 , vx $43.5 \%$ and xg 15.1 min.) and monthly mean values fluctuated $(\mathrm{P}<0.001)$ in a relatively broad range of 7.48 minute (36.1\%). Weak positive correlation was found between the TES (also log TES) and log TCM (total count of microorganisms) and log COLI (count of coli microorganisms) as well (0.169 and 0.124; $\mathrm{P}<0.01 ; \mathrm{n} 1,353$ and 1,355). The somatic cell count (SCC) showed no significant relationship with TES $(\mathrm{P}>0.05)$. The surprising results are probably due to the lower variability and especially TCM, COLI and SCC level (248 $\pm 13910^{3} \mathrm{ml}^{-1}$; xg 218; vx 56.2\%; n 3,253) in the bulk milk. Significant effect on the TES was identified also in farms $(\mathrm{P}<0.001)$. The results should contribute to an effective method of raw milk selection for dairy products with higher thermal stress during processing. The proposed selection limits for farms according to their history to predict better TES of raw material for 2 years of milk collection are: summer, TES mean over 17.5 minutes, variability up to $36.4 \%$; winter, over 13.0 minutes and up to $43.3 \%$.
\end{abstract}

Keywords: dairy cow, Czech Fleckvieh, Holstein, fat, hygienic indicators, proteins, solids non-fat, somatic cell count

\section{INTRODUCTION}

In dairying, as in other professional fields, this is economically important to create higher added value. Milk thermostability (TES) is an important technological property whose knowledge can contribute to creating greater added value in the dairy industry. Milk thermostability (TES; lactoprotein thermostability) is a property that implies the resistance of milk proteins to thermal coagulation respectively to thermal denaturation and may be impaired by a decrease in its quality (Feagan et al., 1966, e.g., due to mastitis). Good raw milk TES is required in the production of durable (with long shelf live) products (condensed and sterilized UHT milk; Patrovský and Gajdůšek, 1988; Singh, 2004). Chramostová et al. (2014) stated 
the TES as an important parameter in assessing the raw milk quality particularly in terms of the heat gains that milk is exposed during its processing. This technology test (TES) is simple, nevertheless labor-intensive and lengthy. Therefore, the data sets for TES studies are of lesser scale in tens of samples as maximum (Chramostová et al., 2014, 2016; Peroutková et al., 2016). That is also reason why the data file used here is exceptional for its frequency. For the reasons given here, the determination of raw milk TES is often replaced by a simpler measurement of the so-called alcohol stability of milk, which is positively correlated with TES. Effects on milk alcohol stability also were studied (Horne and Parker, 1980, 1981, 1982; Gajdůšek, 1989; Horne and Muir, 1990; Genčurová et al., 1993). Further, by relevant scientific studies, the species differences in milk TES as compared cow milk to sheep, goat or camel were recorded (Raynal-Ljutovac et al., 2007; Metwalli et al., 2013; Chramostová et al., 2016).

For the aforementioned reasons the aim of the work was to evaluate the thermostability (TES) of raw bulk cow's milk in practical agricultural production conditions and also TES relations to other milk indicators on the results of an exceptionally large data set of milk samples from the Czech Fleckvieh and Holstein breed.

\section{MATERIALS AND METHODS}

\section{Conditions of cow rearing and bulk milk samples}

During the 3 years, 48 herds of dairy cows of Czech Fleckvieh and Holstein breed $(35$ and 10 and 3 herds of both breeds) which were milked twice a day were included in this survey. Dairy cows were housed in free stables (35) and in binding cowsheds (13) under east Bohemia regional conditions. The milking was carried out in the milking parlor (35) in free stables and into pipeline in binding cowsheads (13). The total number of animals covered and monitored was 8,928 (heads). The number of animals in the herds ranged from 4 to 630 (an average of $186 \pm 164$ dairy cows). The altitude of the herds ranged from 254 to $510 \mathrm{~m}$ with average $347.7 \pm 68.8 \mathrm{~m}$. The average of annual total water precipitation was $554 \pm 143 \mathrm{~mm}$ (from 325 to 750 ). The average delivery of raw milk to the dairy plant was 4,454 $\pm 4,095 \mathrm{~kg}$ (from 60 to 13,870 ) and the average milk yield per dairy cow and standard lactation (305 days) was 6,728 $\pm 2,488 \mathrm{~kg}$ (from 2,033 to 11,124). During the 3-year experimental period 3,310 (n) bulk milk samples (2,829 (n) for TES determination) were taken at two-weekly or monthly intervals. The grazing was applied in the summer feed season in some herds. The frame, total, average composition of the feeding rations (of course, these were fed with volume modifications according to lactation phase and milk yield) was supplemented with the consumption of forage cereal concentrates according to the feed tables for the given milk yield. The quality of the applied complete compound feeding rations in the observation can be considered as moderate overall and especially with regard to the roughage feeding portion. Feeding of animals was mostly carried out in the form of total mixed ration (TMR) using a mobile feeding mixer.

\section{Analysis of bulk milk samples}

The samples were preserved with bronopol (0.03\%) and stored in a refrigerator. Then the samples were transported in cold conditions $\left(<8^{\circ} \mathrm{C}\right)$ to an accredited dairy laboratory (LRM Buštěhrad, ČMSCH a.s.) and analyzed. Values for components (contents) and milk indicators were determined: fat (F); crude protein (CP, total $\mathrm{N} \times 6.38$ ); lactose monohydrate (L); solids non-fat (SNF); urea (U); milk freezing point (MFP); somatic cell count (SCC); total count of mesophilic microorganisms (TCM); count of coli-form bacteria (COLI); milk thermostability (TES); residues of inhibitory substances (RIS, for possible occurrence of antibiotica (drugs) residues and also for interference potential of possible phytoactive substances). In addition, energy (ketose) milk (cow) coefficients F/CP and F/L (Steen et al., 1996; Siebert and Pallauf, 2010; van Knegsel et al., 2010; Hanuš et al., 2013; Manzenreiter et al., 2013) were calculated. Milk analyzes were performed according to relevant methods with calibrated and controlled analytical techniques according to standard operating procedures. The milk components (F, CP, L, SNF, U) and indicators (MFP) were determined by the indirect method of MIR-FT infrared spectroscopy (in mid range with interferometer and Fourier's transformation, in case of MFP with electrical conductivity measurement) CombiFoss FT+ (Foss Electric, Hilleröd, Denmark). The SCC was determined by flow cytometry on the same device. TCM was also determined by flow cytometry using IBC FC (Bentley Instruments, Chaska, Minnesota, USA). The COLI count was determined by plate cultivation method (VRBL agar, $37 \pm 1^{\circ} \mathrm{C}$, abbreviated cultivation period 24-48 hours). The RIS (+/-) were determined by a microbiological (Geobacillus stearothermophilus) inhibition assay (growth at $65^{\circ} \mathrm{C}$ ) with $\mathrm{pH}$ indicator Eclipse 50 (ZEU-INMUNOTEC, Spain). The TES was determined in minutes in non-preserved milk (Janštová and Navrátilová, 2014 a). The time was determined up to visual denaturation (flocculation) of milk proteins when heated in an oil bath at $135^{\circ} \mathrm{C}$. The procedure was carried out with $2.5 \mathrm{ml}$ of milk in a relevant thick-walled glass tube in the Bohemilk Opočno laboratory.

\section{Statistical data treatment and result evaluation}

Mean values (arithmetic mean (x), median (m), variability in the form of standard deviation (sd) and variation coefficient (vx in\%) were calculated for the milk indicators. The indicators (such as SCC, TCM, COLI, TES) with usual absence of normal data frequency distribution (Ali and Shook, 1980; Reneau, 1986; Janů et al., 2007; Hanuš et al., 2009, 
2011) were transformed in logarithmic way ( $\left.\log _{10}\right)$ to following determination of geometric means $(\mathrm{xg})$ and for possibility of reliable statistic testing with parametric t-test. The differences between milk TES according to practice factors were tested by the classic t-test and also study of relations between TES and other milk indicators was made using correlation analyse (MS Excel, Microsoft, Redmond, Washington, USA). This was logically performed on samples where there was a record of correspondence of type and time of analysis and in this way the number of samples (n) was reduced.

\section{RESULTS AND DISCUSSION}

\section{Composition and properties of bulk milk samples and differences by effects}

The basic statistical characteristics of the bulk milk samples are given in Tab. I. The means and variability of milk components and properties are in fairly good consistency with previous reference sets for given conditions (Gajdůšek, 1989; Genčurová et al., 1993; Janů et al., 2007; Hanuš et al., 2009, 2011). The TES mean $(x \pm s x)$ was $20.71 \pm 8.19$ minutes $(n=2,829$, $\mathrm{xg}=19$ and $\mathrm{m}=20$ minutes) and ranged from 3 to
57 minutes. This means that the variation coefficient was $39.6 \%$. TES is therefore one of the indicators with higher variability despite the evaluation of bulk samples, where this variability would still increase logically when individual samples are evaluated. This variability in the area did not change over the years (varied from 37.0 to 40.1 minutes, Fig. 1), as well as the mean values over the years were very similar $(18.27,21.51$ and 21.94 minutes, $\mathrm{n}=834,954$ and 1,041). The difference was 3.67 minutes $=17.7 \%$. Čmelíková (2014) determined the TES of raw cow milk at $140{ }^{\circ} \mathrm{C}$ to precipitate the proteins. The TES of bulk samples from the 6 collection lines ranged from January to May from 6.04 minutes to 21.4 minutes, but the mean milk TES of collection line with lowest stability was 7.06 minutes with the highest then 12.14 minutes. In three years only 2 RIS findings $(0.06 \%, \mathrm{n}=3,310)$ were recorded. This shows good control of the treatment of diseased animals and the value is almost half compared to the mean in the Czech Republic. Therefore, RIS did not affect the results of this study.

Regarding the effect of the calendar month, this is reported overall (3 years) in the graphs in Fig. 2 and 3 in arithmetic ( $\mathrm{x} \pm \mathrm{sx}$ ) and geometric (xg) monthly means. The highest monthly mean was achieved in

I: Basic statistic characteristics of bulk cow milk samples including thermostability

\begin{tabular}{|c|c|c|c|c|c|c|c|c|c|}
\hline & PAR & $\mathbf{n}$ & $\mathbf{x}$ & sd & $\mathbf{v x}$ & $\mathrm{xg}$ & $\mathbf{m}$ & $\min$. & $\max$ \\
\hline \multicolumn{10}{|l|}{ IND } \\
\hline $\mathbf{F}$ & $\%$ & 3,233 & 3.89 & 0.38 & 9.7 & & 3.86 & 1.75 & 6.58 \\
\hline $\mathbf{C P}$ & $\%$ & 3,255 & 3.4 & 0.19 & 5.6 & & 3.41 & 2.64 & 4.57 \\
\hline $\mathbf{L}$ & $\%$ & 3,255 & 4.89 & 0.12 & 2.5 & & 4.9 & 4.04 & 5.32 \\
\hline SNF & $\%$ & 3,255 & 8.89 & 0.23 & 2.6 & & 8.91 & 7.4 & 10.19 \\
\hline $\mathbf{U}$ & $\mathrm{mg} \cdot 100 \mathrm{ml}^{-1}$ & 1,923 & 24.52 & 6.56 & 26.7 & & 25.0 & 9.0 & 54.0 \\
\hline MFP & ${ }^{\circ} \mathrm{C}$ & 3,255 & -.52575 & .00694 & 1.3 & & -.526 & -.603 & -.415 \\
\hline SCC & $10^{3} \cdot \mathrm{ml}^{-1}$ & 3,253 & 248 & 139 & 56.2 & 218 & 233 & 6 & 1,950 \\
\hline $\log$ SCC & & 3,253 & 2.3375 & 0.2334 & & & 2.3674 & 0.7782 & 3.29 \\
\hline TCM & $10^{3}$ CFU.ml ${ }^{-1}$ & 3,310 & 71.1 & 225.3 & 316.9 & 32.0 & 28 & 1 & 2,999 \\
\hline $\log$ TCM & & 3,310 & 1.503 & 0.4363 & & & 1.4472 & 0 & 3.477 \\
\hline COLI & CFU.ml-1 & 3,310 & 28.8 & 48.8 & 169.7 & 5.0 & 1 & 1 & 169 \\
\hline $\log$ COLI & & 3,310 & 0.6753 & 0.861 & & & 0 & 0 & 2.2279 \\
\hline TES & minute & 2,829 & 20.71 & 8.19 & 39.6 & 19.0 & 20.0 & 3 & 57 \\
\hline $\log$ TES & & 2,829 & 1.2791 & 0.1857 & & & 1.301 & 0.4771 & 1.7559 \\
\hline $\mathbf{F} / \mathbf{C P}$ & & 3,233 & 1.15 & 0.11 & 9.7 & & 1.13 & 0.46 & 2.18 \\
\hline $\mathbf{F} / \mathbf{L}$ & & 3,233 & 0.8 & 0.09 & 10.6 & & 0.79 & 0.34 & 1.48 \\
\hline
\end{tabular}

IND indicator; PAR parameter; $\mathrm{n}$ sample number; $\mathrm{x}$ arithmetic mean; sd standard deviation; vx variation coefficient (\%); xg geometric mean; m median; min. minimum; max. maximum; F fat content; $\mathrm{CP}$ crude protein content; L monohydrate lactose concentration; SNF solids non-fat content; U urea concentration; MFP milk freezing point; SCC somatic cell count; SCC $\log _{10}$; TCM total count of mesophilic microorganisms; TCM $\log _{10}$; COLI coli-form bacteria count; COLI $\log _{10}$; TES milk thermostability; TES $\log _{10}$; F/CP ketosis coefficient fat/crude protein; F/L ketosis coefficient fat/lactose. 
September $(\mathrm{x} \pm \mathrm{sx}=23.98 \pm 7.97, \quad \mathrm{vx}=33.3 \%$ and $\mathrm{xg}=22.4$ minutes) and the lowest value was reached in January ( $\mathrm{x} \pm \mathrm{sx}=16,5 \pm 7.17, \mathrm{vx}=43.5 \%$ and $\mathrm{xg}=15.1$ minutes). Monthly mean values fluctuated in a relatively broad range, indicating a significant impact of the calendar month, 7.48 minutes (36.1\%). Čejna (2006) in individual milk samples showed statistically significant influence of lactation stage on TES, but not for parity. For thematically related assessments, the data set was divided into the winter and summer feeding period (from November to April, from May to October) regarding the calendar months. The mean TES values ( 3 years in total, Tab.
II) ranged from $18.25 \pm 7.68$ to $22.91 \pm 8.0$ minutes $(\mathrm{xg}=16.7$ and 21.4 minutes, $\mathrm{n}=1,335$ and 1,494 ) with variability of 42.1 and $35.0 \%$. The higher relative variability of TES in winter is mainly due to its lower mean value, whereas in summer TES was significantly better. This seasonal difference (ie 4.66 minutes $=22.5 \%)$ was statistically significant $(\mathrm{P}<0.001$; $\mathrm{t}$ test criterion $=15.74$, for $\log \mathrm{TES}$ 15.93) with significant technological advantage in the summer months. The difference was consistent for TES and $\log$ TES also in the same trend in each year. Hypothetically, the more acidic ingredients in winter in cow nutrition (higher proportion of

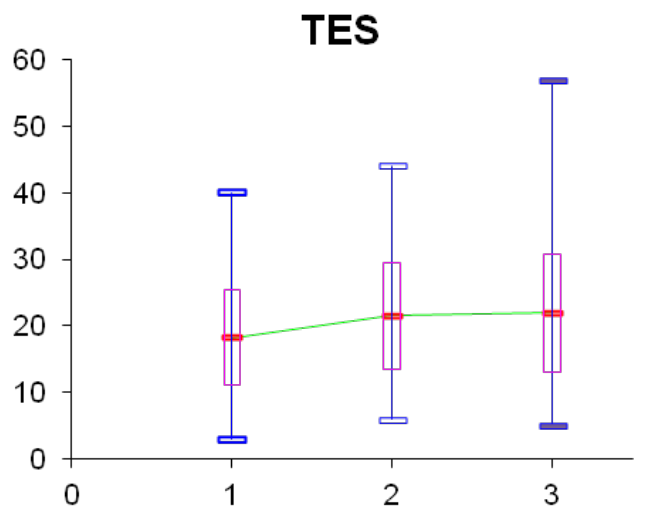

1: Effect of the monitoring year on TES (minute) of raw cow's milk

Construction of box graph: the file median (the central short horizontal line); the top edge of 1st and 3rd quartile (the tetragon); the variation range as difference between maximum an minimum (the vertical line).

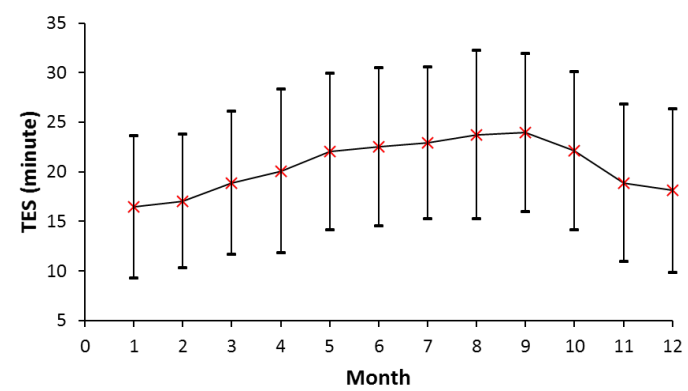

2: Thermostability (TES; minute) of bulk milk samples along calendar months $(x \pm$ sd) during three years (TES in total: number of cases $\mathrm{n}=2,829$; arithmetic mean and standard deviation $\mathrm{x} \pm \mathrm{sd}=20.71 \pm 8.19$ minutes; variation coeficient $\mathrm{vx}=39,6 \%$; geometric mean $\mathrm{xg}=19$ minutes; median $\mathrm{m}=20$ minutes; range of variation from 3 to 57 minutes)

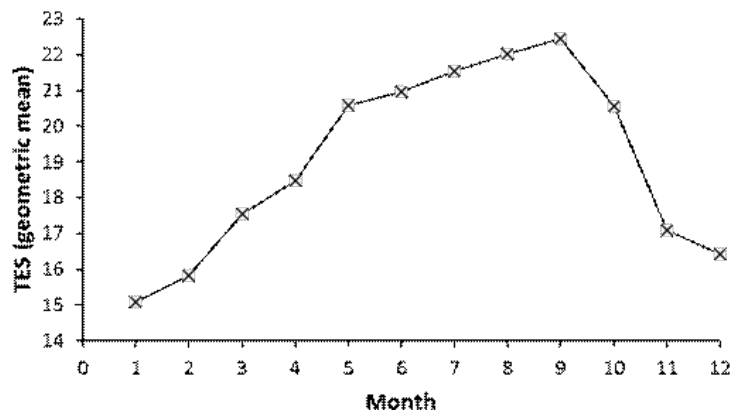

3: Thermostability (TES; minute) of bulk milk samples along calendar months (xg) during three years (according to Fig. 2) 
preserved forage in the roughage portion of feeding ration - silages) than in the summer (with a partial addition of green feed and grazing in the relevant area) can metabolically cause partial physiological exhaustion of milk buffering capacity (MBC) in winter, although $\mathrm{MBC}$ towards the acidic area is more effective than towards alkaline. An important TES factor is pH acidity (Singh, 2004; Kailasapathy, 2008). Then with a faster drop in $\mathrm{pH}$ in the winter (due to partial depletion of MBC) TES may worsen as well as alcohol stability which showed the same trend as Genčurová et al. (1993) reported.

\section{Relationships of TES and other milk indicators}

The selected linear regression relations were calculated in the reduced data sets (Tab. III). Weak positive correlation was found between TES (also $\log$ TES) and $\log$ CPM as well as log COLI (0.169 and $0.124 ; \mathrm{P}<0.01 ; \mathrm{n}=1,353$ and 1,355). This is surprising, as it would rather be possible for a certain $\mathrm{pH}$ binding to hygienic indicators under certain circumstances of milk storage to expect the opposite relationship. Nevertheless, values of hygienic indicators (TCM and COLI) are generally low, and therefore the apparently possible impact on TES was not identified in this file.

The SCC (Tab. III) did not show a significant relationship to TES $(\mathrm{P}>0.05)$, despite a considerable data set size $(\mathrm{n}=1,482)$. This relatively surprising result is probably due to the no too high variability and level of the SCC in the bulk samples $(248 \pm 139$ $\left.10^{3} \mathrm{ml}^{-1} ; \quad \mathrm{xg}=218 ; \quad \mathrm{vx}=56.2 \% ; \quad \mathrm{n}=3,253\right) \quad$ in comparison with the individual samples. Similarly, no significant statistical relationship to TES was found in the fat, lactose and SNF contents $(\mathrm{P}>0.05$, $\mathrm{n}=1,477,1,483$ ). Chramostová et al. (2014) also did not find a significant impact of basic milk indicators on TES. This attributed the possibility that the polyfactorial basis of this property in the given smaller data set of bulk milk samples did not have to manifest. Their mean TES was $18.1 \pm 6.71$ minutes (from 7.8 to 30.95 minutes at $140{ }^{\circ} \mathrm{C}, \mathrm{vx}=37.1 \%$ ). The main nutrient components of milk, proteins, showed a weak statistically significant relationship to TES $(\mathrm{r}=-0.069, \mathrm{P}<0.05, \mathrm{n}=1,483 ;$ Tab. III). Protein variability in bulk milk samples can explain for only $0.47 \%$ of TES variability. Another weak but statistically significant relationship to TES $(\mathrm{r}=0.14 ; \mathrm{P}<0.01 ; \mathrm{n}=835)$ was found in urea. Here too, only $2 \%$ of TES variability can be explained

II: Seasonal effect on raw bulk cow milk TES

\begin{tabular}{|c|c|c|c|}
\hline IND & & TES & $\log$ TES \\
\hline Season & PAR & minute & \\
\hline \multirow[t]{8}{*}{ Winter } & $\mathrm{n}$ & 1,335 & 1,335 \\
\hline & $\mathrm{x}$ & 18.25 & 1.2227 \\
\hline & sd & 7.68 & 0.1853 \\
\hline & $\operatorname{vx}(\%)$ & 42.1 & \\
\hline & $x g$ & 17 & \\
\hline & $\mathrm{m}$ & 17 & 1.2304 \\
\hline & min. & 4 & 0.6021 \\
\hline & $\max$. & 49 & 1.6902 \\
\hline \multirow[t]{8}{*}{ Summer } & $\mathrm{n}$ & 1,494 & 1,494 \\
\hline & $\mathrm{x}$ & 22.91 & 1.3295 \\
\hline & sd & 8.0 & 0.1711 \\
\hline & $\mathrm{vx}(\%)$ & 35.0 & \\
\hline & $x g$ & 21 & \\
\hline & $\mathrm{m}$ & 24 & 1.3802 \\
\hline & $\min$. & 3 & 0.4771 \\
\hline & $\max$. & 57 & 1.7559 \\
\hline \multirow[t]{2}{*}{ Difference } & $\mathrm{t}$ & 15.74 & 15.93 \\
\hline & $\mathrm{P}$ & $* * *$ & $* * *$ \\
\hline
\end{tabular}

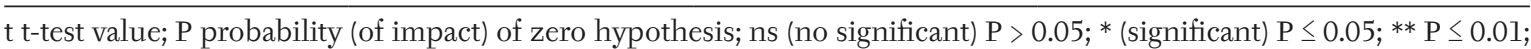
$* * * \mathrm{P} \leq 0.001$ 
III: Relationships between TES and other milk indicators

\begin{tabular}{|c|c|c|c|c|c|}
\hline \multirow[t]{2}{*}{ IND/PAR } & \multirow[b]{2}{*}{ n } & \multicolumn{2}{|l|}{ TES } & \multicolumn{2}{|c|}{ og TES } \\
\hline & & $\mathbf{R}^{2}$ & $\mathbf{r}$ & $\mathbf{R}^{2}$ & $\mathbf{r}$ \\
\hline $\mathbf{F}$ & 1,477 & 0.21 & $-0.046^{\mathrm{ns}}$ & 0.29 & $-0.054^{\mathrm{ns}}$ \\
\hline $\mathbf{C P}$ & 1,483 & 0.43 & $-0.066^{*}$ & 0.47 & $-0.069 *$ \\
\hline $\mathbf{L}$ & 1,485 & 0.14 & $0.037^{\mathrm{ns}}$ & 0.07 & $0.026^{\mathrm{ns}}$ \\
\hline SNF & 1,483 & 0.26 & $-0.051^{\mathrm{ns}}$ & 0.34 & $-0.058^{\mathrm{ns}}$ \\
\hline $\mathbf{U}$ & 835 & 1.96 & $0.14 * *$ & 1.13 & $0.106 * *$ \\
\hline MFP & 1,481 & 0.15 & $-0.039^{\mathrm{ns}}$ & 0.14 & $-0.037^{\mathrm{ns}}$ \\
\hline SCC & 1,482 & 0.07 & $-0.026^{\mathrm{ns}}$ & 0.05 & $-0.021^{\mathrm{ns}}$ \\
\hline $\log$ SCC & 1,482 & 0.11 & $-0.033^{\mathrm{ns}}$ & 0.08 & $-0.028^{\mathrm{ns}}$ \\
\hline TCM & 1,353 & 0.13 & $0.036^{\mathrm{ns}}$ & 0.06 & $0.025^{\text {ns }}$ \\
\hline $\log$ TCM & 1,353 & 2.87 & $0.169 * *$ & 2.46 & $0.157^{* *}$ \\
\hline COLI & 1,355 & 0.79 & $0.089 * *$ & 0.67 & $0.082 * *$ \\
\hline $\log$ COLI & 1,355 & 1.54 & $0.124^{* *}$ & 1.41 & $0.119 * *$ \\
\hline $\mathbf{F} / \mathbf{C P}$ & 1,481 & 0.02 & $-0.014^{\mathrm{ns}}$ & 0.04 & $-0.02^{\mathrm{ns}}$ \\
\hline$F / L$ & 1,477 & 0.27 & $-0.052^{\text {ns }}$ & 0.32 & $-0.057^{\mathrm{ns}}$ \\
\hline
\end{tabular}

$\mathrm{R}^{2}$ determination coefficient (\%); r correlation coefficient.

by $U$ variability. In addition, the result indicates unexpectedly slightly better TES with higher nitrogen load in dairy cows nutrition with a relative lack of energy due to the confrontation of $\mathrm{U}$ and $\mathrm{CP}$ in milk. However, the $\mathrm{U}$ mean values in the data set are common and do not indicate extreme values or variability $(24.52 \pm 6.56 ; \mathrm{vx}=26.7 \% ; \mathrm{n}=1,923$; Tab. I) and therefore neither the identification of the significantly overloaded nitrogen-energy metabolism profile. Chládek and Čejna (2005) did not capture the $U$ effect on TES $(P>0.05)$ in individual milk samples. This does not correspond, for example, to the results of van Boekel et al. (1989, cit. Čejna, 2006). These stated higher protein dissociation for higher U content and then casein molecules are more susceptible to flocculation. However, Čejna (2006) reported the following significant correlation coefficients of TES for individual milk samples: protein -0.352 (-0.284); SNF -0.316; total solids -0.251; F/CP 0.249 (0.301). Kailasapathy (2008) refered to factors such as milk $\mathrm{pH}$, salt content (can be adjusted by salt adding as stabilisation, Janštová and Navrátilová, 2014 b), urea, lactose, protein (and their variants) and also the season, lactation and health of cows as essential for thermostability of milk proteins.

Other statistically insignificant $(P>0.05)$ effects on TES were determined for MFP and F/CP and F/L milk energy coefficients (Tab. III). In the case of evaluation of the energy problems of metabolism (ketosis) as production disorders in milked cows and their herds, these milk coefficients F/CP and F/L (Manzenreiter et al., 2013) are often used. Their values are related to the level of energy metabolism and therefore also positively correlated with other indicators in milk, such as ketones (eg acetone). In this sense, these coefficients were also determined as milk indicators in this data set. The tightness values of correlations of other monitored milk indicators to TES of bulk milk samples surprisingly did not show any narrower relationships in this given large data set. It is possible that for individual milk samples with a logically wider range of variation and many more extreme values possible dependencies could be more observable. However, for practical processing there is used predominantly bulk milk.

\section{Impact of environmental and technological farm conditions on TES}

Significant effect on TES was also identified for the farm $(\mathrm{P}<0.001)$. This effect showed a pronounced tendency to long-term stability with respect to the TES mean and to the equilibrium with respect to the TES variability by farms. This is very important. This stability and equilibrium was probably due to the configuration of technological conditions on the farms. The fluctuations in the variation range of TES mean of herds varied from $12.5(\mathrm{xg}=12, \mathrm{~m}=12, \mathrm{vx}=28.3 \%, \mathrm{n}=42)$ to 28.8 minutes $(\mathrm{xg}=28, \mathrm{~m}=29.5, \mathrm{vx}=22.7 \%, \mathrm{n}=66)$. This is $78.8 \%$ (data file mean 20.7 minutes $=100 \%$, $39.6 \%$ towards minus and $39.2 \%$ towards plus). The range of fluctuations in the TES mean over the reference period of three years is well balanced in terms of distribution of mean values. Therefore, there is an opportunity for selection of raw material 
IV: Derived selectivity criteria for statistical characteristics for better TES (minute) prediction and selection of suitable raw material for bulk cow milk for more demanding heat treatment during technology processing according to relevant farm history (estimated validity for 2 years approximately)

\begin{tabular}{lcc}
\multicolumn{1}{c}{ Season } & TES mean for 3 years & TES variation coefficient for 3 years \\
\hline Summer & over 17.5 minute & up to $36.4 \%$ \\
Winter & over 13.0 minute & up to $43.4 \%$ \\
\hline
\end{tabular}

according to the historical results of farm TES for a longer period to ensure good milk processing. During the three-year period the coefficients of TES variability fluctuated in the range from 19 to $53 \%$, $\mathrm{x}=34.66 \pm 7.723 \%(\mathrm{vx}=22.3 \%), \mathrm{m}=34.5 \%(\mathrm{n}=47)$. The TES prediction for the choice of raw material for heat-demanding milk processing technology is thus defined mainly by the relevant previous farm monitoring. For this selection (Tab. IV) it is suitable to use: 1) a higher TES mean over 17.5 minutes in summer and over 13.0 minutes in winter (for a $75 \%$ one-sided quartile $(\mathrm{x}-\mathrm{sd} \times 0.68) ; 22.91-8.008 \times 0.68$ and $18.25-7.683 \times 0.68) ; 2$ ) a lower coefficient of variability, up to $36.4 \%$ in summer and up to $43.4 \%$ in winter (for $75 \%$ unilateral quartile $(x+s d \times 0.68-3.5 \%$ and $+3.5 \%$ as compensation of difference variability in summer and winter, when the difference between variation coefficients is about $7 \%$ (42.1-35.0\%); $34.66+7.723 \times 0.68-3.5$ and $34.66+7.723 \times 0.68+3.5)$.

\section{CONCLUSION}

Greater knowledge of the statistical characteristics of TES in the dairy plant collection area could be methodically used to predict selective collection of raw materials with appropriate technological properties from chosen farms for more demanding dairy processing of raw cow's milk to products with higher added value.

\section{Acknowledgement}

This contribution was created with the support of the projects NAZV KUS QJ1510339 and MZE RO 1418. Further the authors thank Mr. director Dipl. Eng. Antonín Kolár̆, Mrs. Bc. Jitka Haňková and Mr. Ladislav Havlas from Bohemilk Opočno, Mr. Dipl. Eng. Jan Zlatníček, Mrs. Dipl. Eng. Zdeňka Klímová and Mr.Zdeněk Motyčka from ČMSCH a.s. for their professional and technical cooperation.

\section{REFERENCES}

ALI, A. K. A. and SHOOK, G. E. 1980. An optimum transformation for somatic cells concentration in milk. Journal of Dairy Science, 63(3): 487-490.

ČEJNA, V. 2006. Influence of cow lactation on chosen technological properties of milk. Doctoral Thesis. Mendel University in Brno, Faculty of Agronomy.

ČMELÍKOVÁ, T. 2014. Evaluation of thermal stability of milk [in Czech: Hodnocení termostability mléka]. Bachelor Thesis 18217, University of Chemistry and Technology in Prague.

FEAGAN, J. T., GRIFFIN, A. T., and LLOYD, G. T. 1966. Effects of subclinical mastitis on heat stability of fluid milk. Journal of Dairy Science, 49(8): 933-939.

GAJDU゚ŠEK, S. 1989. The fermentationability, cheeseability and alcohol stability of cow‘s milk and their relationship to the milk composition. Živočišná Výroba / Czech Journal of Animal Science, 34: 413-422.

GENČUROVÁ, V., HANUŠ, O., BEBER, K., KOPECKÝ, J. and HAVLÍČKOVÁ, K. 1993. Relationship between alcohol stability of cow's milk and some components and factors of primary production. Živočišná Výroba /Czech Journal of Animal Science, 38(9): 837-848.

HANUŠ, O., JANU゚, L., VYLETĚLOVÁ, M. and KUČERA, J. 2009. Research and development of a synthetic quality indicator for raw milk assessment. Folia Veterinaria, 53(2): 90-100.

HANUŠ, O., JANU゚, L., SCHUSTER, J., KUČERA, J., VYLETĚLOVÁ, M. and GENČUROVÁ, V. 2011. Exploratory analysis of dynamics of frequency distribution of raw cow milk quality indicators in the Czech Republic. Acta Universitatis Agriculturae et Silviculturae Mendelianae Brunensis, 59(1): 83-100.

HANUŠ, O., VYLETĚLOVÁ-KLIMEŠOVÁ, M., CHLÁDEK, G., ROUBAL, P. and SEYDLOVÁ, R. 2013. Metaanalysis of ketosis milk indicators in terms of their threshold estimation. Acta Universitatis Agriculturae et Silviculturae Mendelianae Brunensis, 61(6): 1681-1692.

HORNE, S. and MUIR, D. 1990. Alcohol and heat stability of milk protein. Journal of Dairy Science, 73(12):3613-3626.

HORNE, D. S. and PARKER, T. G. 1980. The pH sensitivity of the ethanol stability of individual cow milks. Netherlands Milk and Dairy Journal, 34(2): 126-130.

HORNE, D. S. and PARKER, T. G. 1981. Factors affecting the ethanol stability of bovine milk. II. The origin of pH transition. Journal of Dairy Research, 48(2): 285-291. 
HORNE, D. S. and PARKER, T. G. 1982. Factors affecting the ethanol stability of bovine milk. V. Effects of chemical modification of milk protein. Journal of Dairy Research, 49(3): 449-457.

CHLÁDEK, G. and ČEJNA, V. 2005. Effect of urea content on chemical and technological milk indicators in Holstein dairy cows. In: Den mléka 1. (Milk day 1 ${ }^{\text {st }}$, Prague, TIRA s.r.o., pp. 69-70.

CHRAMOSTOVÁ, J., VRZÁKOVÁ, Z., NĚMEČKOVÁ, I. and ČURDA, L. 2014. Heat stability of milk and factors influencing it. (In Czech) Mlékaŕskélisty-zpravodaj, 146: 14-17.

CHRAMOSTOVÁ, J., MÜHLHANSOVÁ, A., BINDER, M., STRMISKA, V., ČURDA, L., HANUŠ, O., KOPECKÝ, J., KLIMEŠOVÁ, M., DRAGOUNOVÁ, H., SEYDLOVÁ, R. and NĚMEČKOVÁ, I. 2016. Heat stability of raw ewe and goat milk. Mlékaŕskélisty-zpravodaj 157, 27(3): 22-26.

JANŠTOVÁ, B. and NAVRÁTILOVÁ, P. 2014 a. Instructions for exercises in technology and hygiene of milk and dairy products. Brno: Institute of Hygiene and Milk Technology, University of Veterinary and Pharmaceutical Sciences.

JANŠTOVÁ, B. and NAVRÁTILOVÁ, P. 2014 b. Milk production and dairy technology. Brno: Faculty of Veterinary Hygiene and Technology, Institute of Hygiene and Milk Technology, University of Veterinary and Pharmaceutical Sciences.

JANUீ, L., HANUŠ, O., BAUMGARTNER, C., MACEK, A. and JEDELSKÁ, R. 2007. The analysis of state, dynamics and properties of raw cow milk quality indicators in the Czech Republic. Acta Fytotechnica et Zootechnica, 10(3): 74-85.

KAILASAPATHY, K. 2008. Chemical composition, physical and functional properties of milk and milk ingredients. In: CHANDAN, R. C., KILARA, A. and SHAH, N. P. (Eds.). Dairy Processing and Quality Assurance. John Wiley \& Sons, pp. 75-103.

KNEGSEL, VAN A. T. M., DRIFT, VAN DER S. G. A., HORNEMAN, M., ROOS, DE A. P. V., KEMP, B. and GRAAT, G. A. M. 2010. Ketone body concentration in milk determined by Fourier transform infrared spectroscopy: Value for the detection of hyperketonemia in dairy cows. Journal of Dairy Science, 93(7): 3065-3069.

MANZENREITER, H., FÜRST-WALTL, B., EGGER-DANNER, C. and ZOLLITSCH, W. 2013. Zur Eignung des Gehalts an Milchinhaltsstoffen als Ketoseindikator. In: 40. Viehwirtschaftliche Fachtagung. Irdning, 18.-19. 4. 2013, pp. 9-19.

METWALLI, A. A., ISMAIL, E. A., ALHAJ, O. A., SALEH, K. A. and IBRAHIM, F. S. 2013. The effect of urea and formaldehyde on heat coagulation time (HCT) of camel milk. Life Science Journal, 10(4): 45-50.

PATROVSKÝ, J. and GAJDŨŠEK, S. 1988. Thermostability of milk with perspective of production of sterilized milk and milk with prolonged shelf live. Prümysl Potravin, Mlékařské Listy, 14: 2.

PEROUTKOVÁ, J., BINDER, M. and DRBOHLAV, J. 2016. Thermal stability of milk fortified with protein preparations [in Czech: Tepelná stabilita mléka obohaceného o bílkovinné preparáty]. Mlékařské listy-zpravodaj 158, 27(5): 12-15.

RAYNAL-LJUTOVAC, K., PARK, Y. W., GAUCHERON, F. and BOUHALLAB, S. 2007. Heat stability and enzymatic modifications of goat milk and sheep milk. Small Ruminant Research, 68: 207-220.

RENEAU, J. K. 1986. Effective use of dairy herd improvement somatic cell counts in mastitis control. Journal of Dairy Science, 69(6): 1708-1720.

STEEN, A., OSTERAS, O. and GRONSTOL, H. 1996. Evaluation of additional acetone and urea analyses, and of the fat-lactose-quotient in cow milk samples in the herd recording system in Norway. Journal of Veterinary Medicine, A43: 181-191.

SIEBERT, F. and PALLAUF, J. 2010. Analyse von Ergebnissen der Milchleistungsprüfung in Hessen im Hinblick auf ein Ketoserisiko. Züchtungskunde, 82(2): 112-122.

SINGH, H. 2004. Heat stability of milk. International Journal of Dairy Technology, 57(2-3): 111-119.

Contact information

Oto Hanuš: hanus.oto@seznam.cz

Eva Samková: samkova@zf.jcu.cz

Gustav Chládek: chladek@mendelu.cz

Marcela Klimešová: marcela.vyletelova@seznam.cz

Petr Roubal: roubal@milcom-as.cz

Irena Němečková: nemeckova@milcom-as.cz

Radoslava Jedelská: radka.jedelska@seznam.cz

Jaroslav Kopecký: jaroslav.kopecky@email.cz 